\title{
Xylanase Production By Thermobacillus Xylanilyticus is Impaired By Population Diversification But Can Be Mitigated Based On the Management of Cheating Behavior
}

\section{Romain Bouchat ( $\nabla$ romain.bouchat@univ-reims.fr)}

Universite de Reims Champagne-Ardenne https://orcid.org/0000-0003-3603-9399

\section{Frédéric Vélard}

Reims Champagne-Ardenne University: Universite de Reims Champagne-Ardenne

\section{Sandrine Audonnet}

Reims Champagne-Ardenne University: Universite de Reims Champagne-Ardenne

\section{Damien Rioult}

Reims Champagne-Ardenne University: Universite de Reims Champagne-Ardenne

\section{Frank Delvigne}

Université de Liège Faculté Universitaire des Sciences Agronomiques de Gembloux: Universite de Liege Gembloux Agro-Bio Tech

\section{Caroline Rémond}

Reims Champagne-Ardenne University: Universite de Reims Champagne-Ardenne

\section{Harivony Rakotoarivonina}

Reims Champagne-Ardenne University: Universite de Reims Champagne-Ardenne

\section{Research}

Keywords: Hemicellulases, Xylanases, Thermobacillus xylanilyticus, successive cultivation, population diversification, cell sorting, substrate switch

Posted Date: November 12th, 2021

DOI: https://doi.org/10.21203/rs.3.rs-1033651/v1

License: (c) (i) This work is licensed under a Creative Commons Attribution 4.0 International License. Read Full License

Version of Record: A version of this preprint was published at Microbial Cell Factories on March 15th, 2022. See the published version at https://doi.org/10.1186/s12934-022-01762-z. 


\section{Abstract}

Background: The microbial production of hemicellulasic cocktails is still a challenge for the sector of biorefineries and agro-waste valorization. In this work, the production of hemicellulolytic enzymes by Thermobacillus xylanilyticus has been considered. This microorganism is of interest since it is able to produce an original set of thermostable hemicellulolytic enzymes, and notably a xylanase GH11, Txxyn11. However, cell-to-cell heterogeneities impairs the production capability of the whole microbial population.

Results: Sequential cultivations of the strain on xylan as a carbon source has been considered in order to highlight and better understand this cell-to-cell heterogeneity. Successive cultivations pointed out a fast decrease of xylanase activity (loss of $~ 75 \%$ ) after 23.5 generations. Accordingly, the expression of the Txxyn11 gene decreased drastically and followed the same trend as the xylanase activity. Flow cytometry analyses pointed out that two subpopulations, differing at the level of their light scattering properties, were potentially involved in this progressive loss of enzymatic activities. Interestingly, upon successive cultivations on xylan, the subpopulation exhibiting low forward scatter (FSC) signal. Additionally, the evolution of the ratio between the two subpopulations was correlated to the decrease in xylanase activity. Cell sorting and direct observation of the sorted subpopulations revealed that the low-FSC subpopulation was not sporulating, whereas the high-FSC subpopulation contained cells at the onset of the sporulation stage. Serial cultivations on glucose, followed by the addition of a xylan pulse led to a $\sim 1.5$-fold to $\sim 15$ fold improvement of xylanase, depending on the moment for pulse addition, , suggesting that alternating cultivation conditions could lead to an efficient population management strategy for the production of xylanase.

Conclusions: Taken altogether, the data from this study point out that a cheating behaviour is responsible for the progressive reduction in xylanase activity during serial cultivations of $T$. xylanilyticus. Alternating cultivation condition between glucose and xylan could be used as an efficient strategy for promoting population stability and higher enzymatic productivity from this bacterium.

\section{Background}

The use of lignocellulosic biomass has been identified as a promising approach in the biorefinery field for the production of bioderived products like energy, fuels, chemicals and materials to substitute the fossil carbon sources causing global warming [1-3]. In this valorization, hemicelluloses offer new possibilities of industrial applications [4]. These ones are heteropolysaccharides and the most abundant are xylans formed by linear chains of D-xylopyranose linked by $\beta-(1-4)$ glycosidic bonds [5]. Some substitutes (depending on the plant origin) such as L-arabinofuranose, D-glucuronic and 4-O-methyl-D-glucuronic acid and acetyl groups can be linked to the main chains by various bonds. In graminaceaous plant cell walls, the L-arabinofuranose residues can be esterified by phenolic compounds such as ferulic and $p$ coumaric acids [5]. Among the different processes that could be used for lignocellulose depolymerization, the use of enzymes from different sources is a very interesting alternative already reviewed [6-9]. In the 
context of this work, the production of hemicelluloses by the bacterium Thermobacillus xylanilyticus will be considered.

This bacterium is indeed a very promising natural producer of enzymes for the deconstruction of xylans [10]. This bacterium was originally isolated from a farm soil located under a manure heap in northern France) is aerobic, gram-positive, thermophilic and hemicellulolytic [11]. The hemicellulolytic enzymatic arsenal of this bacterium is composed by several enzymes including characterized two xylanases (GH10 and GH11 families), one arabinofuranosidase and one feruloyl esterase [12-14]. This bacterium is able to mobilize a complex enzymatic arsenal according to the lignocellulosic biomass composition used as carbon source for promoting microbial growth [15]. The main hemicellulolytic activity of the strain is the GH11 xylanase secreted in the extracellular medium, Tx-xyn11 but it also produces debranching and exoenzymes (such as esterase, xylosidase, and arabinosidase) activities mainly detected in the intracellular compartment $[10,15]$. One important feature of the enzymes produced by $T$. xylanilyticus is that they are thermostable and active over a wide range of $\mathrm{pH}$ values $[13,14,16]$ allowing their use under extreme reaction conditions e.g., for pulp and paper processing at high $\mathrm{T}^{\circ}$ and high $\mathrm{pH}$ ).

However, taking the microbial population out of its natural context for the industrial production of enzymes is still a challenge. Indeed, enzyme production is a highly regulated process, strongly dependent on the extracellular conditions. Additionally, it is known that the release of these enzymes in the extracellular environment can lead to cheating behavior [17]. Cheaters are individuals among the population that benefit from the public goods released by the cooperators (i.e., in T.xylanilyticus case, microbial cells that are investing in enzyme production for the release of assimilable carbon sources), but that do not share the cost associated with the release of these public goods [18]. This is exactly what has been observed in this study, upon serial cultivations of T. xylanilyticus on xylan.

Typically, these cell-to-cell heterogeneity are due to epigenetic mechanisms leading to fluctuations at the level of the biochemical reactions of the cells, and modulating gene expression [19, 20]. In some case, these population heterogeneities are reinforced by fitness advantage (i.e., in this study, benefiting from the release of assimilable sugars without investing in enzyme production) and can cause a decrease of global productivity due to the presence of some specific non-producer (or low-producer) subpopulations $[20,21]$.

For addressing such population heterogeneities, high throughput single-cell analyses can be provided by flow cytometry (FC). In this work, two basic FC signals will be mainly used i.e., the forward and side scatter signals (FSC and SSC), accounting for cell size and cell internal structure [22]. This approach can be complemented based on the utilization of metabolic sensors such as Redox SensorGreen (RSG) that allows to discriminate subpopulations in function of their metabolic activities [23].

The production of specific hemicellulose enzymatic cocktails is a key for improving the profitability of the lignocelluloses biorefineries by using all parts of the lignocellulose [3, 24]. Thermobacillus xylanilyticus represents an interesting source of thermostable and robust hemicellulolytic enzymes. A bottleneck for the utilization of this strain is the low enzyme production and the decrease of secreted xylanase activity 
with thime and over successive cultivations. Accordingly, the main goals of this study are then 1) to study and understand the dynamics of enzyme production by population of T. xylanilyticus, 2) to attempt improving the enzyme productions by the bacteria. For this latter, whereas some cheater control strategies have been suggested $[25,26]$, no real implementation of control/mitigation strategies have been considered so far. In this work, a simple and efficient control strategy will be implemented based on alternative cultivation conditions on glucose and xylan.

\section{Results}

Successive cultivations of T. xylanilyticus on xylan leads to the progressive decline in xylanase activity

In order to characterize the behavior of T. xylanilyticus in presence of xylan and the resulting xylanase production, the growth rate $\left(\mathrm{h}^{-1}\right)$ and its enzymatic activity $(\mathrm{IU} / \mathrm{mg})$ were measured during 107.7 generations. For this purpose, successive cultivation in sealed bottle was considered.

The initial growth rate on xylan for the first cultivation was $0.72 \pm 0.12 \mathrm{~h}^{-1}$ (generation 0 , Table S1), and this value was considered as the reference $(100 \%$, generation 0 , Figure 1$)$. We observed that the growth increased over the generations, this increase being more important during the first generations (increase of $31.56 \%$ after 23.5 generations). A stabilization was then noticed around a value of $0.95 \mathrm{~h}^{-1}$ until the end of the successive cultivation experiment. The xylanase activity, the main enzyme secreted by $T$. xylanilyticus, was also followed. At the beginning of the cultivations, xylanase activity was $141.36 \pm 7.76$ $\mathrm{IU} / \mathrm{mg}$ of proteins. The xylanase activities revealed a drastic decrease over generations, a decrease of almost $88.86 \%$ during the first 23.5 generations followed by a stabilization around a value of $28.10 \pm$ $10.32 \mathrm{IU} / \mathrm{mg}$ (Table S1). At the end of the successive cultivations (after more than 100 generations), the xylanase activity value represented only $18.51 \pm 4.54 \mathrm{IU} / \mathrm{mg}$ i.e., exhibiting a reduction more than $90 \%$ by comparison with the first cultivation.

The evolution of the $t x-x y n 11$ gene expression, encoding the main xylanase GH11 secreted by $T$. xylanilyticus was also assessed along generations during cultivations on xylan and on glucose as a control. At the beginning of the cultivations, and as expected, the expression level of $t x-x y n 11$ gene was very low in presence of glucose. On xylan, $t x-x y n 11$ expression level was almost 30 -fold higher than on glucose (Figure S1), this observation being in accordance with the induction level previously recorded for this strain [15].

Upon successive cultivations on xylan, a progressive decrease of $t x-x y n 11$ expression over the generations was observed (Figure 1B). This decrease accounted for $36.49 \%$ of the maximum level after 23.5 generations by comparison with the tx-xyn11 expression level measured at the beginning of the cultivation tests. After this first decrease, the expression level of $t x-x y n 11$ remained close to $60 \%$ of the initial level for 108 generations. Interestingly, the evolution of the expression level followed the same trend as the one recorded for the enzymatic activity during successive cultivations on xylan (Figure 1A). Gene expression can be thus considered as the main cause for the decrease observed for the xylanase 
activity. Considering the fact that the xylanase is an extracellular enzyme and that some cells can adopt a cheating strategy for avoiding the cost related to the synthesis of this molecule [27], single-cell experiments were then considered for determining the possible impact of cell-to-cell variability on xylanase production.

Flow cytometry (FC) reveals two subpopulations exhibiting different light scattering properties

FC analyses were then performed for determining the possible occurrence of different subpopulations of T. xylanilyticus during the successive cultivation experiments. Results highlighted the presence of two subpopulations in T. xylanilyticus cultivations after 5 hours of cultivations (Figures 2A, 2B and 2C). Indeed, the segregation between the two subpopulations can be observed based on the Forward Scatter (FSC) signal which is proportional to the cell size. A FSC-A threshold value of 30,000 (Arbitrary Unit) can discriminate two subpopulations. The subpopulation with values below 30,000 in FSC-A has been called low subpopulation ( $L$ ) and the subpopulation with values above 30,000 in FSC-A has been called high subpopulation $(H)$.

This clear segregation based on the FSC-A threshold allowed tracking the two subpopulations over the different generations (Figure 3). At the beginning of the cultivations (generation 0 ), the two subpopulations were present at a similar level $(47.09 \pm 11.84 \%$ and $52.91 \pm 11.84 \%$ for the low and the high subpopulation respectively). The evolution of the ratio between the subpopulations over the different generations was marked by an increase of the low subpopulation. This increase was more important during the 23.5 first generations, where the percentage rose from $47.08-73.87 \%$ and then stabilized around $83.77 \%$ for 108 generations.

The two subpopulations did not exhibit any differences upon staining respectively with RedoxSensor green and Propidium lodide (FL1-A and FL3-A values), indicating that it did not differ by their respective metabolic activity and membrane permeability.

Complementary FC analyses were performed on different substrates (i.e., xylan, glucose and wheat bran) in order to better characterize the occurrence of the two subpopulations (Figure 4). Wheat bran was selected as an interesting carbon source, considering its high xylan content [28]. At the beginning of the culture and during the exponential phase (4 hours of cultivations) whatever the substrate used, the low subpopulation was dominant and accounted for $72.1,87.3$ and $84.9 \%$ of the total number of cells on xylan, glucose and wheat bran respectively. At the end of exponential phase on glucose and xylan, an increase of the high subpopulation was observed (Figure 4A and 4B). For wheat bran cultivations, the low subpopulation remained dominant during all the experiment. It is also on wheat bran that less sporulation was always observed. Then, the balance between the two subpopulations seems to be easier to achieve when rich carbon source (i.e., glucose) is considered instead of more difficult to assimilate ones (i.e., xylan and wheat bran). Taken altogether, these data point out a possible occurrence of sporulation. This hypothesis is reinforced by the fact that cells triggering the formation of endospore tend to modify their light scattering properties as detected based on flow cytometry analyses. Accordingly, microscopy analyses will be considered in the next section. 
Cell sorting reveals that the high-FSC subpopulations contains cells at the onset of sporulation

In order to get more insights about the possible physiological differences between the low and the high subpopulations, cells collected from samples acquired during successive cultivations on xylan were sorted based on their FSC properties, and morphological analyses were performed with Scanning Electron Microscopy (SEM). More specifically, the generations for which a strong modification of the enzyme activity was recorded were analyzed i.e., the 20th generation (G20) and the 50th generation (G50). The SEM pictures revealed that two types of morphologies were present at $\mathrm{GO}$ after $5 \mathrm{~h}$ of cultivation (Figure $5 A$ ) i.e., either very long (or dividing) cells and sporulating cells. After cell sorting of the two subpopulations at G0, the high subpopulation contained cells with well-formed sporangia in central position (Figure 5B). Some sporulating cells were also observed in low subpopulation but at an earlier sporulation stage (Figure 5C). From G20 to G50, a predominance of the low subpopulation was observed by flow cytometry, most of the cells being in the vegetative state (at the same cultivation time) up to G50 (Figure 5D). The cell sorting at G20 and G50 revealed the predominance of the low subpopulation with vegetative cells (Figure $5 \mathrm{E}$ ).

These observations confirmed the morphological and physiological diversification of the subpopulations upon successive cultivations and the progressive decrease of the high subpopulation. It also correlated the high subpopulation with cells exhibiting advanced sporulation stage and the low subpopulation containing vegetative cells.

In order to determine the impact of this diversification process on the production of extracellular xylanase by T. xylanilyticus, the low and the high subpopulations were sorted and subcultivated. The cell sorting was done at generation 0 , after 5 hours of cultivation during the exponential growth phase (Figure $6 \mathrm{~A}$ ) when the two subpopulations were present similarly at approximately the same ratio.

The growth rate and the xylanase activity for each subpopulation were assessed in the presence of xylan. A common feature observed for the two subpopulations was the lag phase, which was very long, probably due to the very low inoculum used after cell sorting. However, the lag phase was longer for the low subpopulation (Figure 6B). The growth began after 5 hours for the high subpopulation and after 10 hours of incubation for the low subpopulation. However, the duration of exponential growth phase was similar for the two subpopulations. (3, 5 and 4 hours for the low and high subpopulation respectively) with growth rates of $0.55 \pm 0.01 h^{-1}$ and $0.82 \pm 0.02 h^{-1}$ respectively.

About the xylanase activity, a difference of xylanase activity was noticed at the beginning and at the onset of the exponential phase. The xylanase activity production was 3.5-fold higher for the high subpopulation by comparison with the production level of the low subpopulation at the beginning of the exponential phase $(\sim 0.52 \pm 0.00 \mathrm{IU} / \mathrm{mL}$ vs $\sim 0.15 \pm 0.21 \mathrm{IU} / \mathrm{mL}$ for the high and low subpopulations respectively) (Figure $6 \mathrm{C}$ ). At the end of the exponential phase, a difference between the two subpopulations was observed as the xylanase activity produced by the high subpopulation was 1,89-fold higher than the one observed for the low subpopulation. A sharp increase of xylanase production was 
observed between the end of exponential phase and stationary phase $(1.33 \pm 0.5 \mathrm{IU} / \mathrm{mL}$ to $3.89 \pm 0.14$ $\mathrm{IU} / \mathrm{mL}$ and $2.52 \pm 0.06 \mathrm{IU} / \mathrm{mL}$ to $4.43 \pm 0.61 \mathrm{IU} / \mathrm{mL}$ for the low and high subpopulations respectively) with the two subpopulations exhibiting similar level of xylanase concentration after this phase.

Improving the xylanase production based on a cheater management strategy

As shown in the previous section, the presence of a subpopulation exhibiting reduced extracellular enzyme production during successive cultivations led to a global decrease of xylanase production by $T$. xylanilyticus. This low, non-producing, subpopulation was considered as a cluster of cheater cells. In order to validate this hypothesis, and as an attempt to control the occurrence of cheater cells, successive cultivations on glucose instead of xylan were considered. Indeed, glucose being an easily accessible carbon source, its utilization was considered to mitigate the occurrence of sporulation. For this, $T$. xylanilyticus was cultivated during the successive cultivations experiment on glucose and carbon source shifts from glucose to xylan were done to evaluate the impact on xylanase production. The occurrence of the two subpopulations was done on flow cytometry analyses and xylanase production was also assessed (Table S2 and Figure 7).

The growth rate on glucose at the beginning of the cultivations (generation 0 ) was $0.87 \pm 0.05 \mathrm{~h}^{-1}$ and did not change significantly over the generations considering the standard deviations (Figure 7A).

At the beginning of the cultivation, the measured xylanase activity represented $217.07 \pm 84.20 \mathrm{IU} / \mathrm{mg}$ of proteins (values closed to the ones obtained at generation 0 on xylan successive cultivations, $141.36 \pm$ $7.77 \mathrm{IU} / \mathrm{mg}$ of proteins, considering the standard deviations). The xylanase enzymatic activity after the carbon source switch (from glucose to xylan) over the different generations pointed out a stabilization of the production and the enzymatic levels quantified were comprised between $217.07 \pm 84.20$ and $288.55 \pm$ $10.70 \mathrm{IU} / \mathrm{mg}$ between generations 0 to 79.9 with a peak at $346.99 \pm 47.07 \mathrm{IU} / \mathrm{mg}$ after 42.7 generations (Figure 7A). In contrast to the experiments carried out on xylan, no significant loss of activity was observed when xylan was replaced by glucose. The level of xylanase activity was relatively high for all the generations when glucose was used as the main carbon source and subpopulations were switched to xylan at the end of each cultivation cycle. Globally the production of xylanase by T. xylanilyticus over successive cultivations was stabilized when glucose was used as the amin carbon source (data from Table S2, by comparison with data from Table S1).

The flow cytometry analyses performed during the successive cultivations on glucose pointed out the presence of the two previously observed subpopulations (low and high) such as for the successive cultivations on xylan. Figure 7B showed that, at the beginning of the experiment, the low subpopulation represented $73.36 \pm 7.13 \%$ of the total population. Over successive cultivations on glucose, the percentage of cells into the high subpopulation increased up to $64.51 \%$ after 42.7 generations where the maximal level of xylanase activity was obtained. On the opposite, successive cultivations on xylan led to a drastic reduction of the high subpopulation. 


\section{Discussion}

Successive cultivation tests pointed out a population degeneration effect at the level of extracellular xylanase activity by T. xylanilyticus. This decrease was linked with a significant drop at the level of the transcriptional activity linked to this enzyme and was characterized for the first time for this bacterium. This kind of production decrease has already been observed for many other microorganisms (bacteria and fungi) of industrial interest [29]. The main question is to know whether this decrease can be attributed to a global reduction of enzyme production by all the cells within the population or due to a subpopulation of cells. Single-cell analyses revealed that two subpopulations were generated during the successive cultivations on xylan i.e., a subpopulation exhibiting a low FSC signal and the other exhibiting a high FSC signal. Such modulation of the FSC signal suggests a significant alteration of the cellular morphology [30]. According to microscopy observations, the high subpopulation comprised cells in a premature stage of sporulation (onset to sporulation being triggered during the exponential phase). Upon cell sorting and subcultivation, the high subpopulation exhibited a shorter lag phase and an earlier xylanase production, suggesting that these sporulating cells are still able produce the target enzyme. These differences at the level of the enzyme production capability suggest that a cheating mechanism can be at the origin of the population degeneration effect observed during successive cultivation. The cheater phenotype is prone to appear when microbial population relies on an extracellular enzymatic production to degrade complex substrates into an usable [31, 32]. In T. xylanilyticus case, since xylanase is excreted to the extracellular medium, some cells can avoid the metabolic burden associated with the production of this enzyme but still take benefit from the monomers released by the active members of the population [17].

According to these observations, a preliminary model can be advanced (Figure 8). At the population level (Figure 8A), diversification and split into two subpopulations with distinct FSC properties are observed during the exponential phase. In this case, the premature sporulation can be due to the metabolic burden carried by the non-cheating cells. At the single-cell level, the picture is more complex (Figure 8B). First, if there is a need for a better characterization of the population dynamics, the transition rates between the main phenotypes (either productive or non-productive cells) and morphotypes (either sporulating or nonsporulating cells) need to be quantified. Additionally, a series of unknown remains i.e., some transitions that have not been considered in the initial view of the process (delineated by red arrows on Figure 8B). However, a common observation is that the "sporulating" state can be easily detected based on single-cell technologies and could be used as a proxy for detecting population degeneration. Some studies have already proven the presence of sporulating cells or morphologically different cells directly impacting the productivity of the process such as Clostridia [33, 34]. Advanced single-cell technologies could be implemented in order to refine the resolution about microbial population dynamics. Among them, singlecell cultivation microfluidics could be used for tracking cells and determining more precisely the transition rate between the different morphotypes [35]. Another alternative would be to use automated flow cytometry and feedback control. Such technologies have already been used for characterizing population dynamics of Gram-negative bacteria based on an approach called segregostat [36, 37]. 


\section{Conclusions}

This study pointed out the importance of populations diversification processes during long-time cultivation experiments. Four main observations can be highlighted: 1 ) the strain degeneration at the level of xylanase production from T. xylanilyticus along generations on xylan (decrease of $88.86 \%$ after 23.5 generations); 2) the presence of two different populations for this bacterium; 3 ) the difference between the two populations (the low population which is not sporulating but less producing and the high population which is sporulating but more producing) and the impact of balancing the two population on the xylanase production (selection of the low population along generations with xylanase production decrease); 4) the impact of substrate switching (from glucose to xylan) on populations stability according to xylanase activity (increase of 1.54 -fold) and stability of this production with no more decrease of xylanase production along generations. All these elements open up new perspectives for the effective control of population diversification, notably by using advanced single-cell technologies.

In this work, a strategy relying on the alternance between glucose and xylan was used effectively to mitigate the diversification of the population based on the FSC signal, leading to an improved xylanase production during successive cultivation. This strategy has been notably applied in adaptive evolution studies by switching between cellobiose and glucose in order to obtain Thermobifida fusca strain exhibiting higher cellulase production [38]. In T. xylanilyticus case, phenotypic diversification is more likely to occur, and such strategy could be implemented into a more sophisticated control procedure relying on automated single-cell measurement in order to prevent the appearance of cheaters during successive or long-term continuous cultivations.

\section{Methods}

Strains and media

Thermobacillus xylanilyticus XE9/11/91 isolated from a farm soil under a manure heap in northern France was used in this study. The bacterium was cultivated on basal medium composed by three different solutions, a macro-mineral solution, a vitamin solution, and a metallic trace solution complemented with $\mathrm{NH}_{4} \mathrm{Cl}(1 \mathrm{~g} / \mathrm{L})$, yeast extract $(2 \mathrm{~g} / \mathrm{L}), \mathrm{NaHCO}_{3}$ and supplemented with $10 \% \mathrm{CO}_{2}$ as previously described by [11]. Cultivation volumes are $10 \mathrm{~mL}$ or $50 \mathrm{~mL}$ of media in sealed contents (100 $\mathrm{mL}$ or $500 \mathrm{~mL}$ bottles). Various carbon sources were used: xylan from beechwood $5 \mathrm{~g} / \mathrm{L}$ (Roth), glucose 5 $\mathrm{g} / \mathrm{L}$ (Sigma Aldrich) or destarched wheat bran $10 \mathrm{~g} / \mathrm{L}$ (ARD Pomacle-Bazancourt, France).

\section{Successive cultivations of Thermobacillus xylanilyticus}

The strain was regenerated from glycerol stock and an overnight non sporulated preculture (OD $600 \mathrm{~nm}$ between 1.5 and 2) was prepared on glucose basal medium at $50^{\circ} \mathrm{C}$ and 150 RPM in glucose basal medium with Multitron shakers (Infors). The xylan media (in $50 \mathrm{~mL}$ volume) were inoculated with the preculture to reach a start optical density of 0.1 for the cultivations start. The cultivation was done at $50^{\circ} \mathrm{C}, 150$ RPM during 5 hours in xylan basal medium. After 5 hours, a new cultivation was started from 
the previous one. The successive cultivation was performed every 5 hours (Figure 9). Each 4 cultivations (G20 or generation 23.5, G50 or generation $50.8, \mathrm{G} 80$ or generation 80.3 and $\mathrm{G} 100$ or generation 107.7 for xylan), a following of the growth was done by measuring the $\mathrm{OD} 600 \mathrm{~nm}$. The growth rate was calculated during the exponential phase with the formula: $\mu_{\max }=\ln \left(\mathrm{N}_{2} / \mathrm{N}_{1}\right) / \mathrm{t}_{2}-\mathrm{t}_{1}$ with $\mathrm{N}$ representing the bacterial population (here the optical density measured) and the cultivation time. The generation numbers ( $n$ ) were directly calculated with the formula: $\mathrm{n}=\mathrm{T} / \mathrm{g}$ where $\mathrm{g}$ represents the generation time $\left(\mathrm{g}=\ln 2 / \mu_{\max }\right)$ and $\mathrm{T}$ the total cultivation time. Successive cultivations experiment was performed in triplicate for 17 serial transfers (corresponding to more than 100 generations).

For the followed generations, population analyses were also done by cytometry, xylanase activity production and the xylanase (tx-xyn11) gene expression measured. Figure 9 summarizes the main experiments performed during the successive cultivations.

Measurements of the xylanase enzymatic activity

To evaluate the xylanase activity secreted by T. xylanilyticus, for each followed generation, new $6 \mathrm{~h}$ (to reach the early stationary phase) cultivations on xylan in $10 \mathrm{~mL}$ were prepared. At the end of the cultivations, samples were centrifuged at $3354 \times \mathrm{g}$ for 10 minutes (Sorvall ST 8R centrifuge, Thermo Fisher Scientific) at $4^{\circ} \mathrm{C}$ and the supernatant was recovered. The xylanase activity was determined in triplicate by using the reducing end sugars measurement according to the procedure described by [39].

Briefly, $0.1 \mathrm{~mL}$ of the supernatants (diluted or not) are incubated in $0.9 \mathrm{~mL}$ beechwood xylan (Roth) at $0.5 \% \mathrm{w} / \mathrm{v}$ homogeneously suspended in $50 \mathrm{mM}$ sodium acetate buffer $(\mathrm{pH}$ of 5.8$)$ at $60^{\circ} \mathrm{C}$ for 10 minutes. The reducing sugars were measured by following the absorbance at $420 \mathrm{~nm}$ on a Specord 200 Plus uv/vis spectrophotometer (Analytik Jena) and by comparing the values with a standard curve done with varying concentrations of xylose. The activity was expressed in IU/mL. One international unit (IU) of enzyme activity was defined as the quantity of enzyme (xylanase) required to liberate one $\mu \mathrm{mol}$ of equivalent xylose per minute at $60^{\circ} \mathrm{C}$.

The IU values were normalized with the quantity (in $\mathrm{mg}$ ) of total protein in the supernatants. The concentrations of total protein in the samples were determined by the Bradford procedure [40] with a commercial reagent $5 \times$ (Serva) as recommended by the supplier. After normalization, the activity was expressed in IU by milligrams of total proteins (IU/mg).

Measurements of the $t x-x y n 11$ gene expression

The cultivation samples for gene expression $(5 \mathrm{~mL})$ were centrifuged at $3354 \times \mathrm{g}$ for 10 minutes (Sorvall ST $8 \mathrm{R}$ centrifuge, Thermo Fisher Scientific) at $4^{\circ} \mathrm{C}$. Cell pellets were kept in $1.5 \mathrm{~mL}$ of RNAlater at $-80^{\circ} \mathrm{C}$ before the analyses. The cells pellets were used for RNA extraction with RNeasy Mini Kit (Qiagen) by following the supplier recommendations. The obtained RNA solutions were treated with RNase-Free DNase Set (Qiagen) to prevent the presence of DNA in the samples. Absence of DNA was verified by polymerase-chain reaction with DreamTaq ${ }^{\text {TM }}$ Hot Start Green PCR Master Mix (Thermo Fisher Scientific) 
by using specific primers for $t x-x y n 11$ gene, followed by electrophoresis migrations on RNase-free TBE buffer $1 \times$ agarose gel $1 \%$ (Mupid® ${ }^{\circledR}$ One Electrophoresis System, Eurogentec). The RNA concentrations were determined using a Qubit ${ }^{\mathrm{TM}}$ Fluorometer and Qubit ${ }^{\circledR}$ RNA Assay Kit (Invitrogen).

First strand cDNAs were synthesized by using SuperScript ${ }^{\circledR}$ IV First-Strand cDNA Synthesis Reaction kit (Thermo Fisher Scientific) with $500 \mathrm{ng}$ of total RNA in presence of random hexamer primers $(50 \mu \mathrm{M})$, DNTP mix ( $0.5 \mathrm{mM}$ of each), $1 \times$ SuperScript IV buffer, DTT (100 mM), RNAseOUT ${ }^{\mathrm{TM}}$ Recombinant RNase Inhibitor $(2 \mathrm{U} / \mu \mathrm{L}$ ) and $800 \mathrm{U}$ (or $40 \mathrm{U} / \mu \mathrm{L}$ ) of Superscript IV reverse transcriptase in a final volume of 20 $\mu \mathrm{L}$. The synthesis was done at $23^{\circ} \mathrm{C}$ for 10 minutes followed by a step at $52.5^{\circ} \mathrm{C}$ for 10 minutes. An inactivation was done at $80^{\circ} \mathrm{C}$ for 10 minutes. The generated cDNAs were kept at $-80^{\circ} \mathrm{C}$ until utilization.

Quantitative PCR was realized with a QuantStudio ${ }^{\text {TM }} 3$ Real-Time PCR System (Applied Biosystems ${ }^{T M}$ ) to determine the $t x$-xyn 11 gene expression. Specific primers (forward primer: GACGGCACGCAGACGTTCCA, reverse primer: GCCTTCGGTTGCGAGCACCT) previously described [41] was used and yielded a specific $162 \mathrm{bp}$ long product. Before utilization, the specificity of the primers was tested and confirmed.

The amplifications were performed in $15 \mu \mathrm{L}$ final volume containing $7.5 \mu \mathrm{L}$ of Absolute Blue qPCR SYBR green low ROX mix (Thermo Fisher Scientific), $1.4 \mu \mathrm{L}$ of primers mix $(280 \mathrm{nM}), 1.1 \mu \mathrm{L}$ of DNase/RNasefree water and $5 \mu \mathrm{L}$ template cDNA (10-fold diluted).

The PCR program was the following: an initial denaturation of $95^{\circ} \mathrm{C}$ for $15 \mathrm{~s}$ followed by 40 cycles of $95^{\circ} \mathrm{C}$ for $10 \mathrm{~s}, 60^{\circ} \mathrm{C}$ for $45 \mathrm{~s}$ with a single fluorescence measurement before an elongation step of $72^{\circ} \mathrm{C}$ for $30 \mathrm{~s}$. The specificity of the PCR products was confirmed by melting curve analysis (after a step at $95^{\circ} \mathrm{C}$ for $15 \mathrm{~s}$, the melting curve analysis was performed between $60-95^{\circ} \mathrm{C}$ with a heating rate of 0.1 $\mathrm{C}^{\circ} / \mathrm{s}$ ). Different non-template controls and positive controls (with genomic DNA of T. xylanilyticus) were also included to confirm the specificity of the reactions. The $t x-x y n 11$ transcripts were normalized by using the expression of T. xylanilyticus 16S rRNA gene amplified by using the specific primers (forward primer: CGCGAGCGACGCAATCCCA, reverse primer: CGGTTACCCCACCGGCTTCG). For the relative expression of $t x-x y n 11$ gene, calculation was done using the $2^{-\Delta \Delta C t}$ method [42]. For the quantification of $t x-x y n 11$ transcripts over generations, the expressions of $t x-x y n 11$ at the beginning of the successive cultivations (generation 0 ) were used as reference samples. In order to compare, the expression of $t x$ xyn11 gene between glucose and xylan successive cultivations, the reference sample was defined as the first cultivation on glucose. The results were expressed as the fold increase of mRNA level over the reference samples. Quantitative PCR was realized in triplicates for each sample of successive cultivations.

Population analyses by flow cytometry

Population analyses at the different generations described above (for the successive cultivations) were done by flow cytometry with a BD Accurit ${ }^{\text {TM }} \mathrm{C} 6$ (BD Biosciences) using the MOBICYTE core facilities (University of Reims Champagne-Ardenne). The analytical parameters were flow rate of $35 \mu \mathrm{L} / \mathrm{minute}$, 
core size of $16 \mu \mathrm{m}$ and the threshold were down to 30000 in FSC-H. 20000 cells were collected for each sample.

Samples taken at different generations $(5 \mathrm{~mL})$ were filtered with $5 \mu \mathrm{m}$ cellulose syringe filters and diluted with PBS $1 \times$ to reach maximum 2500 detected events/s (and events/ $\mu \mathrm{L}$ ) to prevent doublet reading. Samples were analyzed first unstained, and populations were detected by the forward and scatter signals (respectively FSC-A and SSC-A) to determine cell percentage of each detected population with a gating at 30000 in FSC-A. The BD CSampler Software was used to acquire and treat the cytometric data.

Samples were also analyzed after staining with BacLight ${ }^{\mathrm{TM}}$ RedoxSensor ${ }^{\mathrm{TM}}$ Green (RSG, $1 \mu \mathrm{M}$ ) or propidium iodide (PI, $10 \mathrm{mg} / \mathrm{L}$ ) (Invitrogen) to detect the metabolic activity and the membrane permeability respectively $[43,44]$. After $488 \mathrm{~nm}$ laser excitation, green fluorescence were collected at 525 $\mathrm{nm} \pm 30 \mathrm{~nm}$ for RSG (FL1-A) and the red fluorescence signal at 670LP (FL3-A) for PI.

Cells were also analyzed at different growth phases (exponential phase, stationary phase and sporulation) on different carbon sources (glucose, xylan and destarched wheat bran) with the same cytometric parameters.

Cell sorting

The cell sorting was realized from T. xylanilyticus cultivated on xylan basal medium at the generation 0 but also along generations (G20 and G50). The cell sorting was performed with a BD FACSAria ${ }^{\mathrm{TM}} \|$ II Cell Sorter coupled with the BD Accuri ${ }^{\text {TM }}$ C6 Plus flow cytometer from the URCACyt technical platform facilities.

In order to standardize the signals of the BD Accurit ${ }^{\mathrm{TM}}$ C6 Plus flow cytometer and BD FACSAria ${ }^{\mathrm{TM}}$ II cell sorter, an analysis of $2.5 \mu \mathrm{m}$ microbeads (BD Biosciences) was done with both systems.

$5 \times 10^{6}$ events were collected for each population and the rate of sorting was around 2500 events/second with a $70 \mu \mathrm{m}$ nozzle. Each cell sorting was performed in triplicate. The events were collected in $10 \mathrm{~mL}$ of PBS 1x. To check for a correct cell sorting, an analysis of each population collected was done with BD Accuri $^{\text {TM }}$ C6 plus flow cytometer. Each population solution was then centrifuged at $12108 \times \mathrm{g}$ (Sorvall ST $8 \mathrm{R}$ centrifuge, Thermo Scientific) for 30 minutes at room temperature. The cell pellet conserved in $100 \mu \mathrm{L}$ of $1 \times$ PBS was solubilized with $1 \mathrm{~mL}$ of xylan basal medium. All the cell solution was used to inoculate a new cultivation on xylan and characterize the separated populations.

Cultivations of the sorted populations

Population cultivations were performed as described in the previous parts for 19 hours. The growth was followed with regular measurement of the $O_{600 \mathrm{~nm}}$. At the different growth phases determined (lag, beginning and end of the exponential phase and stationary phase), samples of $5 \mathrm{~mL}$ were taken and centrifuged at $3354 \times \mathrm{g}$ for 10 minutes (Sorvall ST $8 \mathrm{R}$ centrifuge, Thermo Scientific). The supernatants 
were used for the measurements of xylanase activity and protein contents according to the procedures described above.

Scanning electron microscopy analyses

During the followed successive cultivations, samples were taken before and after the cell sorting for analyses. Before the cell sorting, drops of $20 \mu \mathrm{L}$ were dried on glass coverslip. After the cell sorting, $10 \mathrm{~mL}$ of different sorted populations (at 500 cells by $\mu \mathrm{L}$ corresponding to $5 \times 10^{6}$ ) were concentrated by centrifugation at $16000 \times \mathrm{g}$ for 40 minutes. The cell pellets were solubilized in $500 \mu \mathrm{L}$ and $22.5 \mu \mathrm{L}$ drops were dried on glass slide (corresponding to 225000 cells).

After drying, glass slides were washed 2-times in 1× PBS, then fixed in 2.5\% (W/V in PBS) glutaraldehyde (Sigma-Aldrich) at room temperature for 1 hour. After 2 distilled water washing, cells were dehydrated at room temperature in graded ethanol solutions $(50,70,90$, and twice with absolute ethanol) for 10 minutes and in a solution of ethanol (100\%)/hexamethyldisilazane (V/V) for 5 minutes. Glass slides were finally desiccated with one final drop of HMDS. After air-drying at room temperature, samples were sputtered with a thin gold-palladium film using a JEOL ion sputter JFC 1100 instrument. Samples were then observed using a Schottky Field Emission Scanning Electron Microscope (JEOL JSM-7900F).

Successive cultivation on glucose

Successive cultivations were also performed by using glucose as carbon source during 80 generations. For the generations 23.9, 42.7, 62.9 and 79.9 (due to a different growth rate than on xylan), a switch of the carbon source between glucose and xylan was performed and the same analyses (flow cytometry and xylanase activity) as those for xylan successive cultures were done.

\section{Declarations}

Ethics approval and consent to participate

Not applicable

Consent for publication

Not applicable

Availability of data and materials

The datasets used and/or analyzed during the current study are available from the corresponding author on reasonable request

Competing interests

The authors declare that they have no competing interests. 
Funding

Not applicable

Authors' contributions

RB, CR and HR designed the experiments; RB performed the cultivation, enzymatic assays and flow cytometry experiments; DR helped for some cytometric analyses; SA performed cell sorting experiments; FV performed scanning electron microscopy analyses; RB, FD, CR and HR wrote and revised the manuscript; DR, SA and FV revised the manuscript.

Acknowledgements

The authors thank the PICT-URCA platform (University of Reims Champagne-Ardenne) for imaging core facilities.

Author details

1 Université de Reims Champagne Ardenne, INRAE, FARE, UMR A 614, Chaire AFERE, 51097 Reims, France. ${ }^{2}$ Laboratory of Microbial Processes and Interactions, TERRA Teaching and Research Centre, Gembloux Agro-Bio Tech, University of Liege, Avenue de la Faculté 2B, B140, B-5030 Gembloux, Belgium. ${ }^{3}$ Université de Reims Champagne Ardenne, BIOS EA 4691 "Biomatériaux et Inflammation en site osseux", 51097 Reims, France. ${ }^{4}$ Université de Reims Champagne-Ardenne, URCACyt, Flow Cytometry Technical Platform, 51096 Reims, France. ${ }^{5}$ Université de Reims Champagne-Ardenne, Plateau Technique Mobile de Cytométrie Environnementale MOBICYTE, 51097 Reims, France.

\section{References}

1. Lashof DA, Ahuja DR. Relative global warming potentials of greenhouse gas emissions. Nature. 1990;344:529-31.

2. Naik SN, Goud V V., Rout PK, Dalai AK. Production of first and second generation biofuels: A comprehensive review. Renew. Sustain. Energy Rev. 2010.

3. Chandel AK, Garlapati VK, Singh AK, Antunes FAF, da Silva SS. The path forward for lignocellulose biorefineries: Bottlenecks, solutions, and perspective on commercialization. Bioresour Technol [Internet]. Elsevier; 2018;264:370-81. Available from: https://doi.org/10.1016/j.biortech.2018.06.004

4. Qaseem MF, Shaheen H, Wu AM. Cell wall hemicellulose for sustainable industrial utilization. Renew Sustain Energy Rev [Internet]. Elsevier Ltd; 2021;144:110996. Available from: https://doi.org/10.1016/j.rser.2021.110996

5. Ebringerová A, Heinze T. Xylan and xylan derivatives - Biopolymers with valuable properties, 1: Naturally occurring xylans structures, isolation procedures and properties. Macromol Rapid Commun. 2000;21:542-56. 
6. Bhat MK. Cellulases and related enzymes in biotechnology. Biotechnol Adv. 2000;18:355-83.

7. Dodd D, Cann IKO. Enzymatic deconstruction of xylan for biofuel production. GCB Bioenergy. 2009;1:2-17.

8. Deutschmann R, Dekker RFH. From plant biomass to bio-based chemicals: Latest developments in xylan research. Biotechnol Adv [Internet]. Elsevier B.V.; 2012;30:1627-40. Available from:

http://dx.doi.org/10.1016/j.biotechadv.2012.07.001

9. Binod P, Gnansounou E, Sindhu R, Pandey A. Enzymes for second generation biofuels: Recent developments and future perspectives. Bioresour Technol Reports [Internet]. Elsevier; 2019;5:317-25. Available from: https://doi.org/10.1016/j.biteb.2018.06.005

10. Samain E, Touzel JP, Brodel B, Debeire P. Isolation of a thermophilic bacterium producing high levels of xylanase. Xylans Xylanases, Prog Biotechnol. Elsevier; 1992. p. 467-70.

11. Touzel JP, O'Donohue M, Debeire P, Samain E, Breton C. Thermobacillus xylanilyticus gen. nov., sp. nov., a new aerobic thermophilic xylan-degrading bacterium isolated from farm soil. Int $\mathrm{J}$ Syst Evol Microbiol. 2000;

12. Samain E, Debeire P, Touzel JP. High level production of a cellulase-free xylanase in glucose-limited fed batch cultures of a thermophilic Bacillus strain. J Biotechnol. 1997;

13. Debeche T, Cummings N, Connerton I, Debeire P, O'Donohue MJ. Genetic and biochemical characterization of a highly thermostable ??-L- arabinofuranosidase from Thermobacillus xylanilyticus. Appl Environ Microbiol. 2000;

14. Rakotoarivonina $\mathrm{H}$, Hermant B, Chabbert B, Touzel JP, Remond C. A thermostable feruloyl-esterase from the hemicellulolytic bacterium Thermobacillus xylanilyticus releases phenolic acids from nonpretreated plant cell walls. Appl Microbiol Biotechnol. 2011;90:541-52.

15. Rakotoarivonina $H$, Hermant $B$, Monthe $N$, Rémond $C$. The hemicellulolytic enzyme arsenal of Thermobacillus xylanilyticus depends on the composition of biomass used for growth. Microb Cell Fact. 2012;11:1-12.

16. Debeire-Gosselin M, Loonis M, Samain E, Debeire P. Purification and properties of a $22 \mathrm{kDa}$ endoxylanase excreted by a new strain of thermophilic Bacillus. Prog. Biotechnol. 1991.

17. García-Contreras R, Loarca D. The bright side of social cheaters: Potential beneficial roles of "social cheaters" in microbial communities. FEMS Microbiol Ecol. 2021;97:1-6.

18. Smith P, Schuster M. Public goods and cheating in microbes. Curr Biol [Internet]. Elsevier; 2019;29:R442-7. Available from: http://dx.doi.org/10.1016/j.cub.2019.03.001

19. Casadesús J, Low DA. Programmed heterogeneity: Epigenetic mechanisms in bacteria. J Biol Chem. 2013;288:13929-35.

20. Delvigne F, Zune Q, Lara AR, Al-Soud W, Sørensen SJ. Metabolic variability in bioprocessing: Implications of microbial phenotypic heterogeneity. Trends Biotechnol. 2014.

21. Dragosits $M$, Mattanovich D. Adaptive laboratory evolution - principles and applications for biotechnology. Microb Cell Fact. 2013;12:1-18. 
22. Müller S, Nebe-Von-Caron G. Functional single-cell analyses: Flow cytometry and cell sorting of microbial populations and communities. FEMS Microbiol Rev. 2010;34:554-87.

23. Baert J, Delepierre A, Telek S, Fickers P, Toye D, Delamotte A, et al. Microbial population heterogeneity versus bioreactor heterogeneity: Evaluation of Redox Sensor Green as an exogenous metabolic biosensor. Eng Life Sci. 2016;

24. Kumar R, Singh S, Singh O V. Bioconversion of lignocellulosic biomass: Biochemical and molecular perspectives. J Ind Microbiol Biotechnol. 2008;35:377-91.

25. Strassmann JE, Queller DC. Evolution of cooperation and control of cheating in a social microbe. Proc Natl Acad Sci U S A. 2011;108:10855-62.

26. Wechsler T, Kümmerli R, Dobay A. Understanding policing as a mechanism of cheater control in cooperating bacteria. J Evol Biol. 2019;32:412-24.

27. Perkins TJ, Swain PS. Strategies for cellular decision-making. Mol Syst Biol [Internet]. Nature Publishing Group; 2009;5:1-15. Available from: http://dx.doi.org/10.1038/msb.2009.83

28. Rakotoarivonina $\mathrm{H}$, Hermant $\mathrm{B}$, Monthe $\mathrm{N}$, Rémond $\mathrm{C}$. The hemicellulolytic enzyme arsenal of Thermobacillus xylanilyticus depends on the composition of biomass used for growth. Microb Cell Fact. 2012;11.

29. Peng M, Liang Z. Degeneration of industrial bacteria caused by genetic instability. World J Microbiol Biotechnol [Internet]. Springer Netherlands; 2020;36:1-16. Available from: https://doi.org/10.1007/s11274-020-02901-7

30. Bouchedja DN, Danthine S, Kar T, Fickers P, Sassi H, Boudjellal A, et al. PH level has a strong impact on population dynamics of the yeast Yarrowia lipolytica and oil micro-droplets in multiphasic bioreactor. FEMS Microbiol Lett. 2018;365:1-10.

31. Velicer GJ. Social strife in the microbial world. Trends Microbiol. 2003;11:330-7.

32. Allison SD. Cheaters, diffusion and nutrients constrain decomposition by microbial enzymes in spatially structured environments. Ecol Lett. 2005;8:626-35.

33. Jones DT, Van Der Westhuizen A, Long S. Solvent production and morphological changes in Clostridium acetobutylicum. Appl Environ Microbiol. 1982;43:1434-9.

34. Kashket ER, Zhi-Yi Cao. Clostridial strain degeneration. FEMS Microbiol Rev. 1995;17:307-15.

35. Täuber S, Golze C, Ho P, Von Lieres E, Grünberger A. DMSCC: A microfluidic platform for microbial single-cell cultivation of: Corynebacterium glutamicum under dynamic environmental medium conditions. Lab Chip. Royal Society of Chemistry; 2020;20:4442-55.

36. Nguyen TM, Telek S, Zicler A, Martinez JA, Zacchetti B, Kopp J, et al. Reducing phenotypic instabilities of a microbial population during continuous cultivation based on cell switching dynamics. Biotechnol Bioeng. 2021;118:3847-59.

37. Sassi H, Nguyen TM, Telek S, Gosset G, Grünberger A, Delvigne F. Segregostat: a novel concept to control phenotypic diversification dynamics on the example of Gram-negative bacteria. Microb Biotechnol. 2019;12:1064-75. 
38. Deng Y, Fong SS. Laboratory evolution and multi-platform genome re-sequencing of the cellulolytic actinobacterium Thermobifida fusca. J Biol Chem. 2011;286:39958-66.

39. Kidby DK, Davidson DJ. Ferricyanide Estimation of Sugars in the Nanomole Range. Anal Biochem. 1973;55:321-5.

40. Marion M. Bradford. A rapid and sensitive method for the quantitation of microgram quantities of protein utilizing the principle of protein-dye binding. Anal Biochem. 1976;72:248-54.

41. Rakotoarivonina H, Hermant B, Aubry N, Rabenoelina F, Baillieul F, Rémond C. Dynamic study of how the bacterial breakdown of plant cell walls allows the reconstitution of efficient hemicellulasic cocktails. Bioresour Technol [Internet]. Elsevier Ltd; 2014;170:331-41. Available from: http://dx.doi.org/10.1016/j.biortech.2014.07.097

42. Livak KJ, Schmittgen TD. Analysis of relative gene expression data using real-time quantitative PCR and the 2- $\Delta \Delta C T$ method. Methods. 2001;25:402-8.

43. Konopka MC, Strovas TJ, Ojala DS, Chistoserdova L, Lidstrom ME, Kalyuzhnaya MG. Respiration response imaging for real-time detection of microbial function at the single-cell level. Appl Environ Microbiol. 2011;77:67-72.

44. Davey HM, Hexley P. Red but not dead? Membranes of stressed Saccharomyces cerevisiae are permeable to propidium iodide. Environ Microbiol. 2011;13:163-71.

\section{Figures}




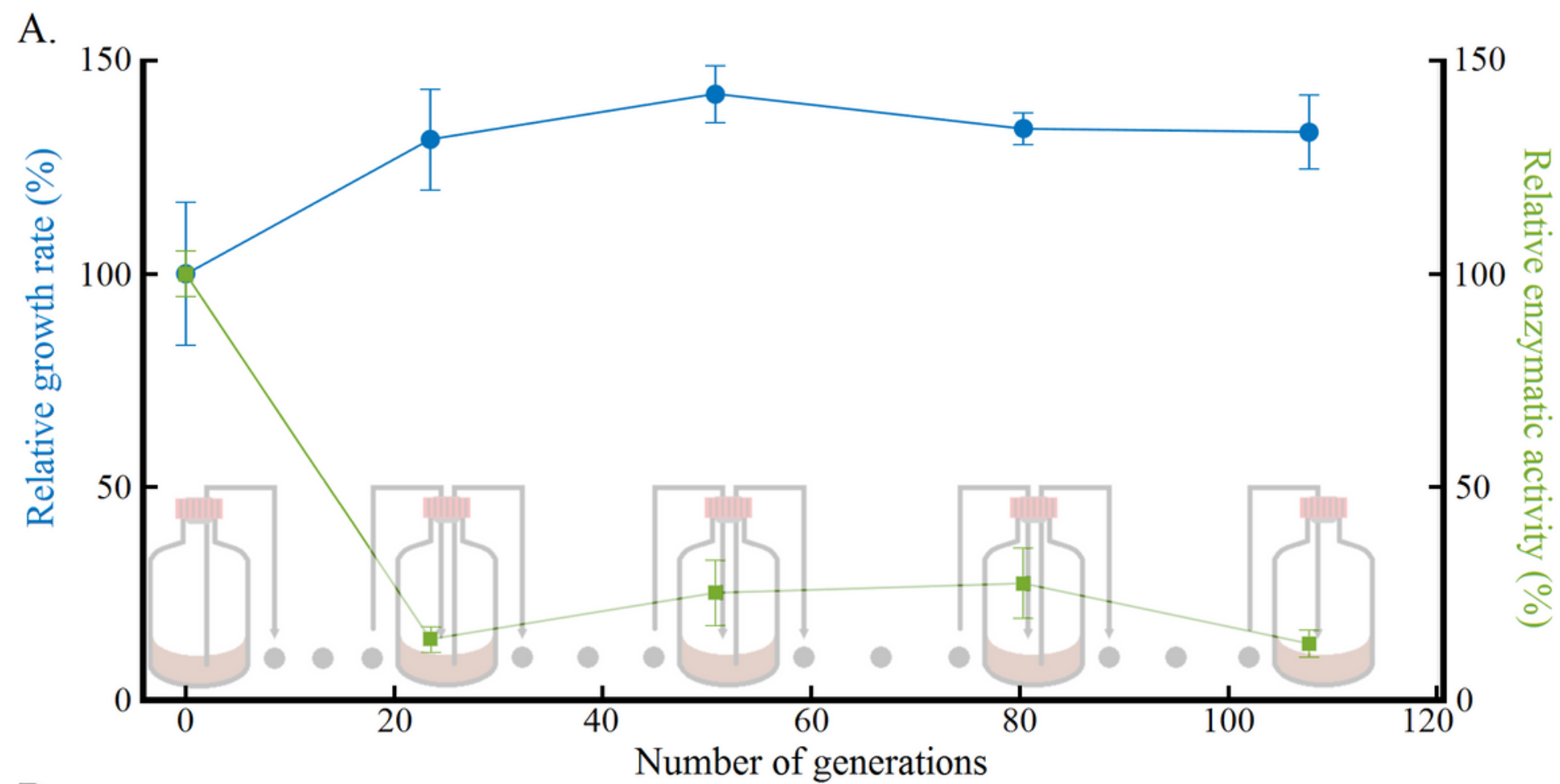

B.

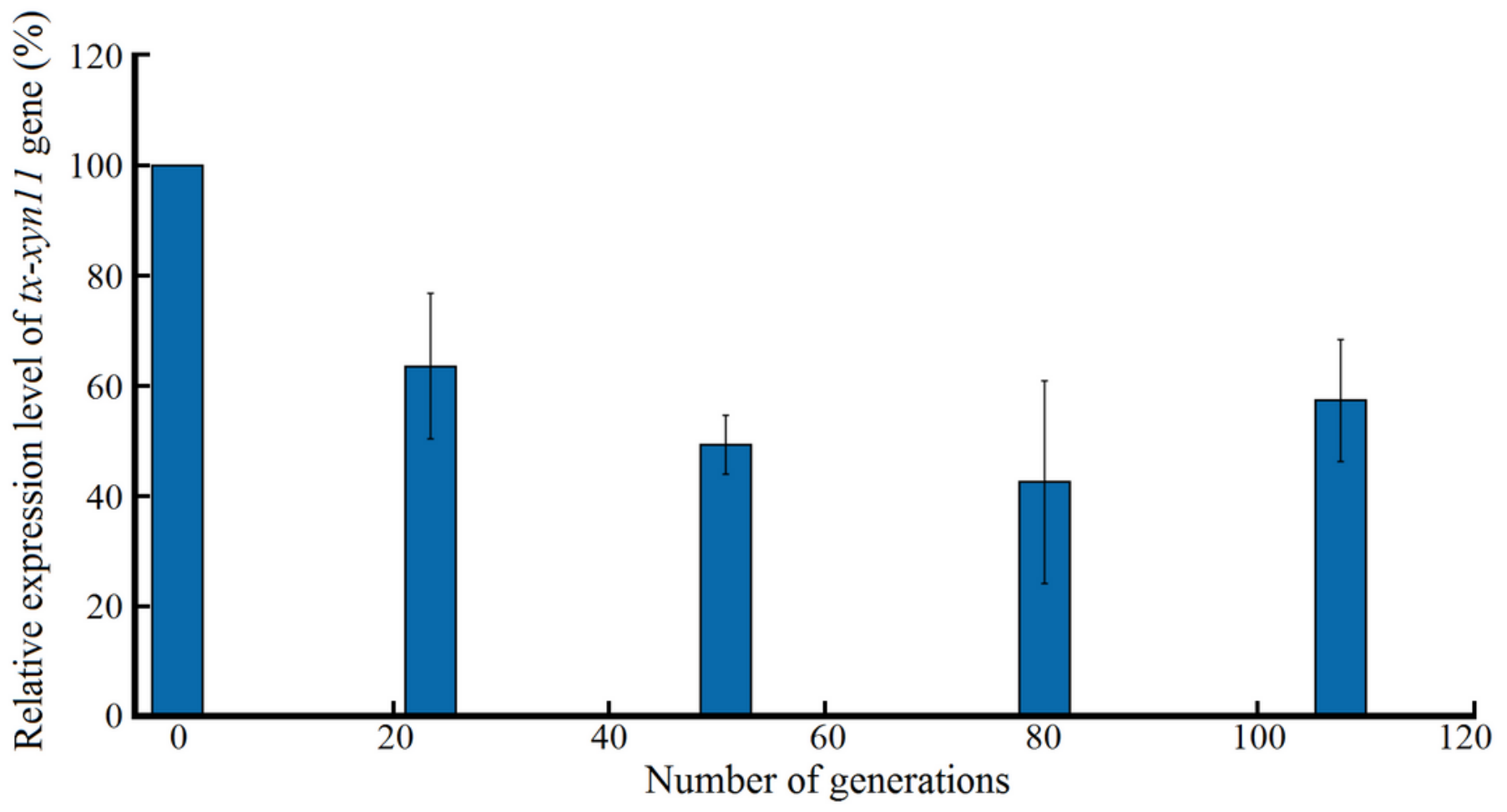

Figure 1

Evolutions of growth rate and xylanase production characteristics of Thermobacillus xylanilyticus over generations. Evolution of relative growth rate (blue circles) and relative xylanase activity (green square) over generations normalized with the values at generation $0(A)$; Relative expression level of $t x-x y n 11$ gene over generations (B). Absolute values of growth rate and enzymatic activity can be found in Table S1. The level of tx-xyn11 gene expression was normalized with the 16S rRNA gene expression before 
comparison along the generations during successive cultivations with xylan. The first cultivation (generation 0) was then defined as the $100 \%$ expression level and as reference sample. The expression levels over the generations were expressed as the fold increase of tx-xyn11 mRNA level over the generation 0.

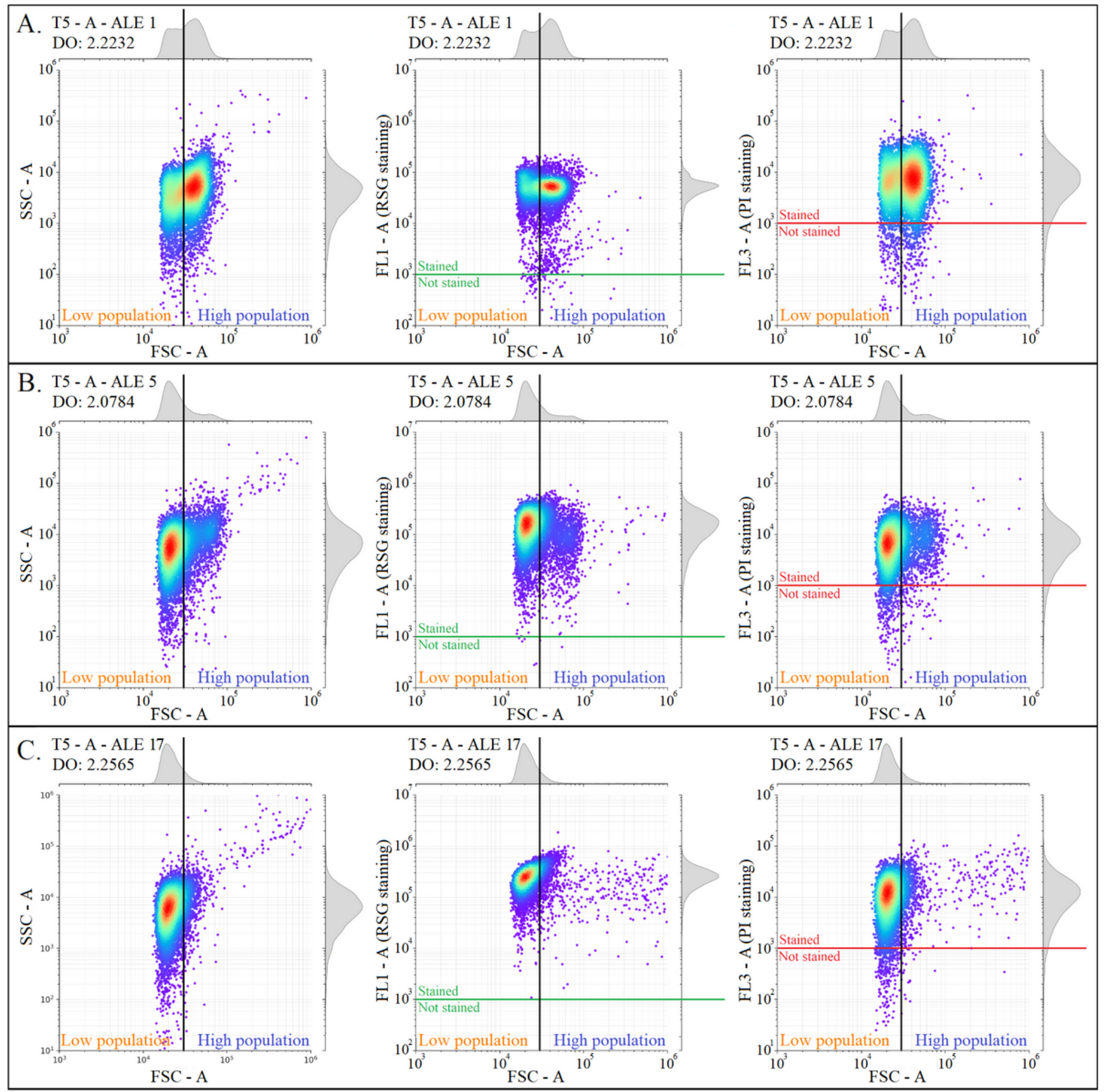

\section{Figure 2}

Subpopulations of Thermobacillus xylanilyticus analyzed by flow cytometry during successive cultivations on xylan. The subpopulations were resolved based on the FSC-A values. The segregation 
between the two subpopulations was done by considering a gating value of 30,000 in FSC-A (orange line). The figures represent the SSC-A values (on the left), the FL1-A values (on the middle) and the FL3-A values (on the right) in function of the FSC-A values. Generations 0 (A); 23.5 (B) and 107.7 (C) respectively.

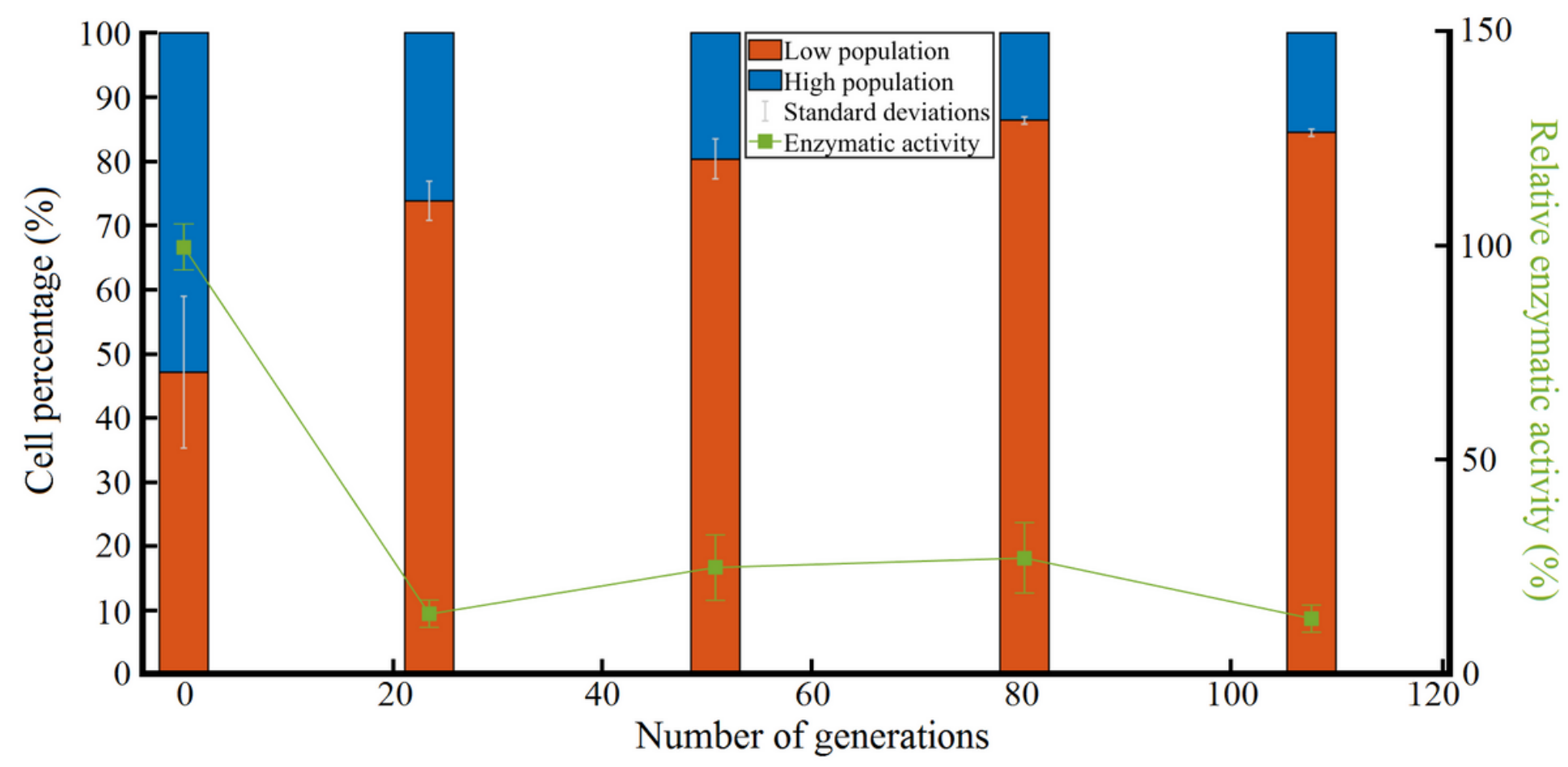

\section{Figure 3}

Evolution of each subpopulation cell percentage and xylanase activity upon successive xylan cultivations. The orange and blue bars represent the means of cells belonging to the low and high subpopulation respectively. The standard deviations are represented by white lines. The evolution of the enzymatic activity expressed in IU/mg of proteins (green lines) is also presented. 

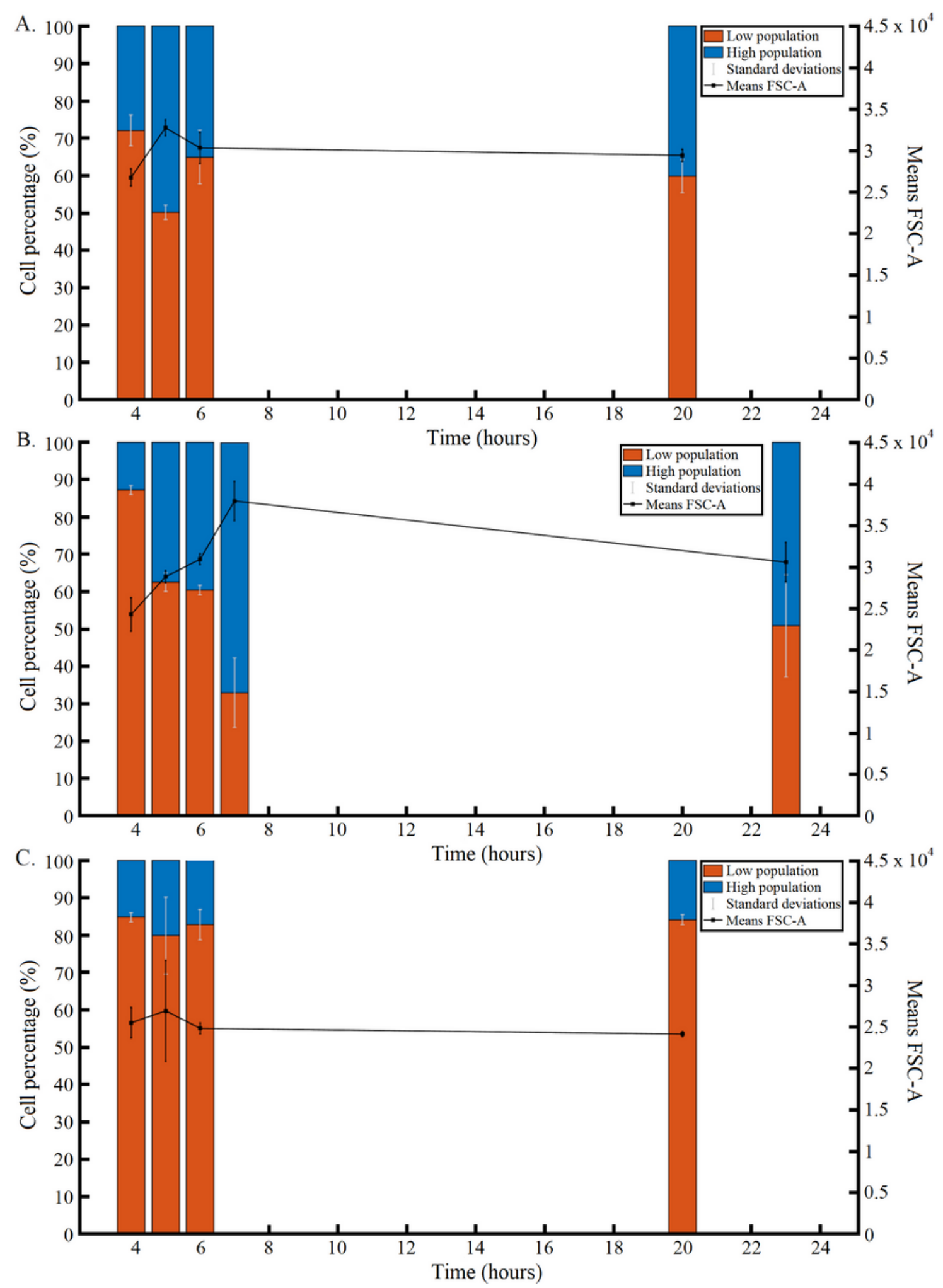

Figure 4

Physiological changes of T. xylanilyticus detected by flow cytometry on different substrates. The substrates considered are either xylan (A), glucose (B) and wheat bran (C). 


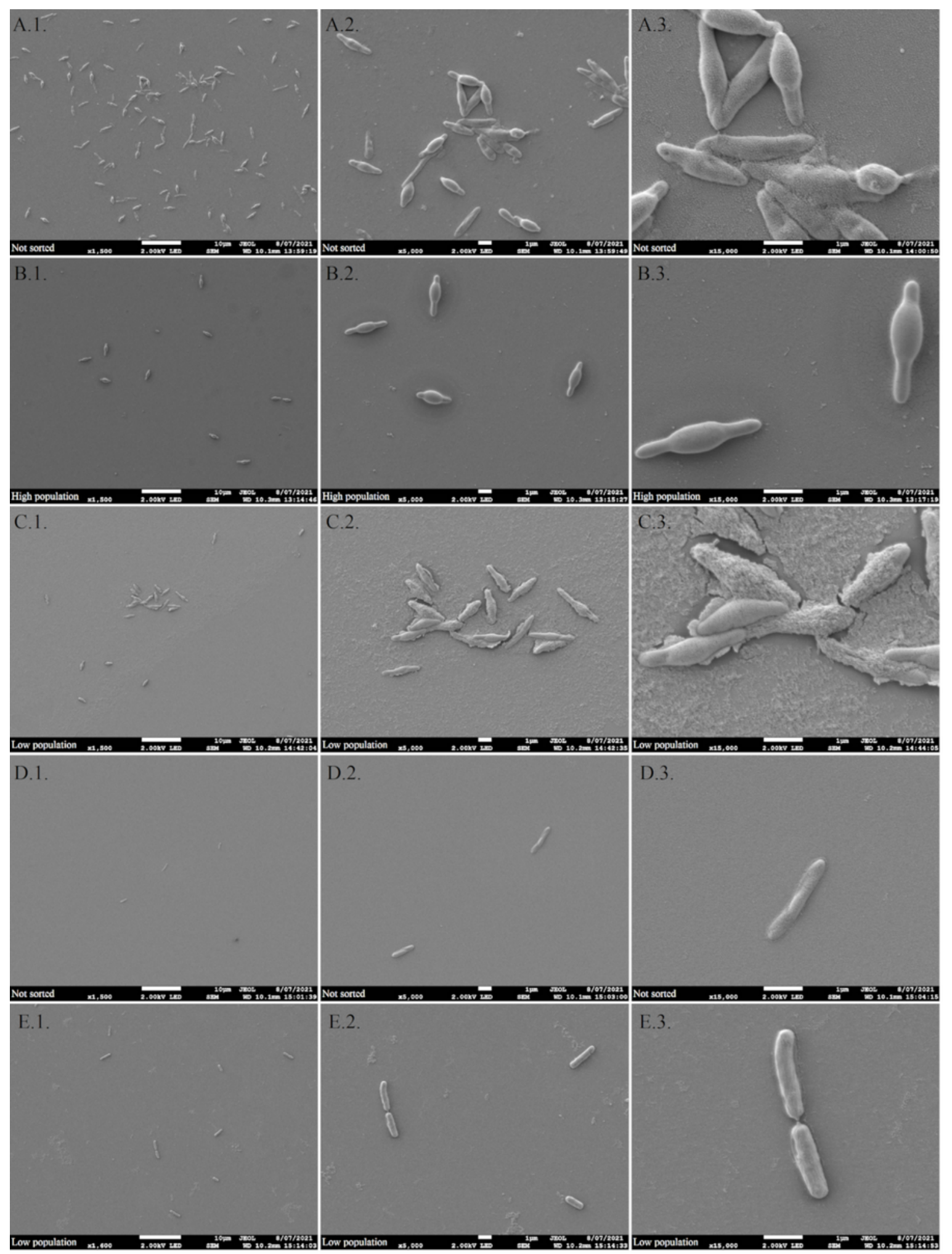

\section{Figure 5}

Morphological changes along the generations. Cells were observed by SEM at magnification 1500 -fold (1), 5000 -fold (2) and 15000-fold (3). Generation 0 not sorted (A), generation 0 sorted to obtain high subpopulation (B), generation 0 sorted to obtain low subpopulation (C), G50 not sorted (D) and G50 after cell sorting $(\mathrm{E})$. 

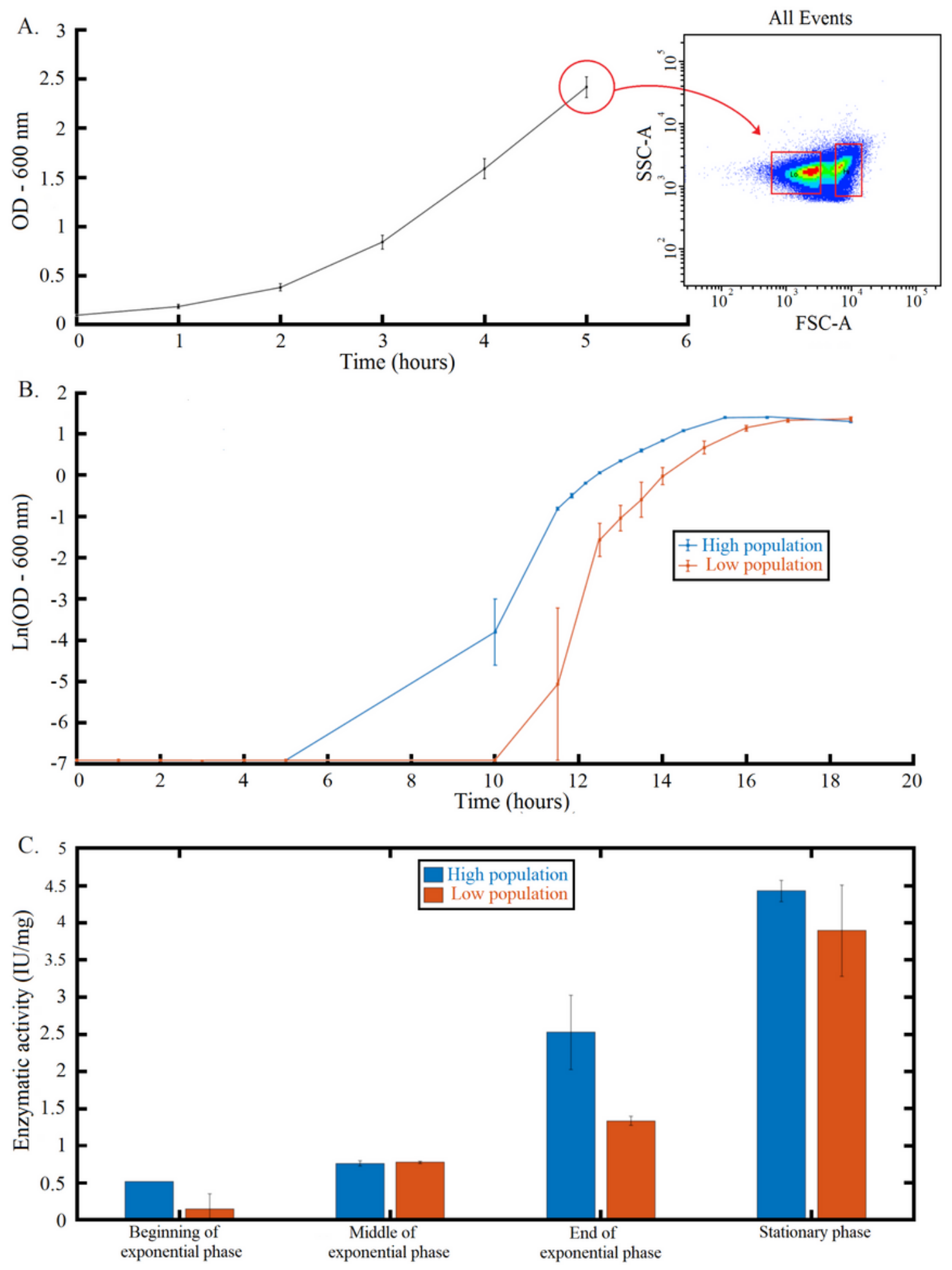

Growth stage

Figure 6

Characterization of the two subpopulations of T. xylanilyticus. Growth and flow cytometry profiles of generation 0 cultivations before cell sorting (A). The red boxes on the FSC-SSC dotplot represent the gates used for discriminating the two subpopulations; Growth profiles of the two subpopulations (B); Xylanase activities for the two subpopulations at different growth phases (C). The blue lines and bars represent the high subpopulation, and the orange ones represent the low subpopulation. 

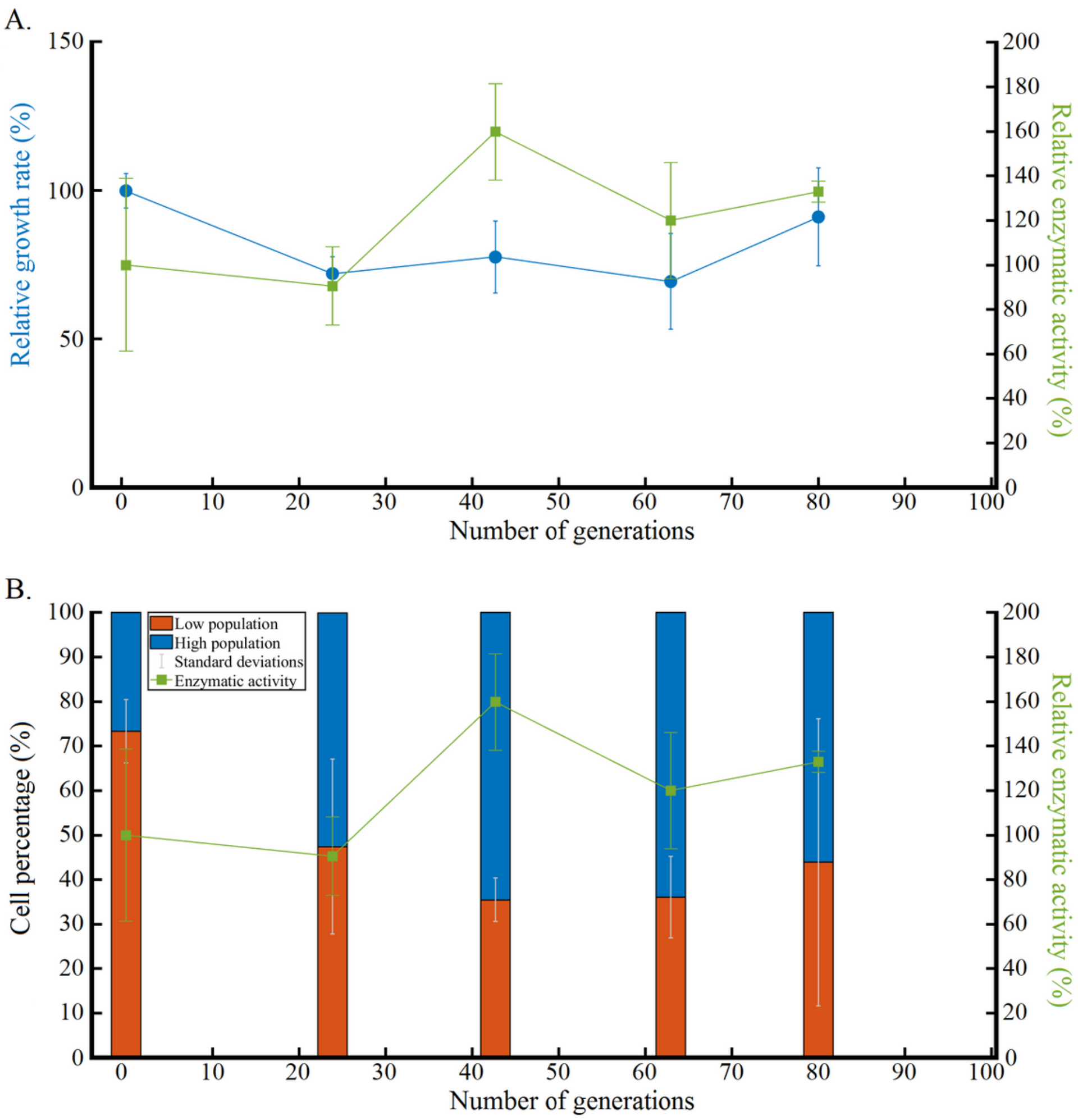

Figure 7

Evolution of Thermobacillus xylanilyticus subpopulations during successive cultivations on glucose, xylanase activity being recorded after switching on xylan. Relative evolution of the growth rate (blue circles) and enzymatic activity after substrate switch (green squares) over generation (A); Evolution of cell subpopulations in percentage over generations after flow cytometry analyses (B). The xylanase 
activity was measured after a switch of carbon source from glucose to xylan at the same growth stage (green lines in A and B).

A

B
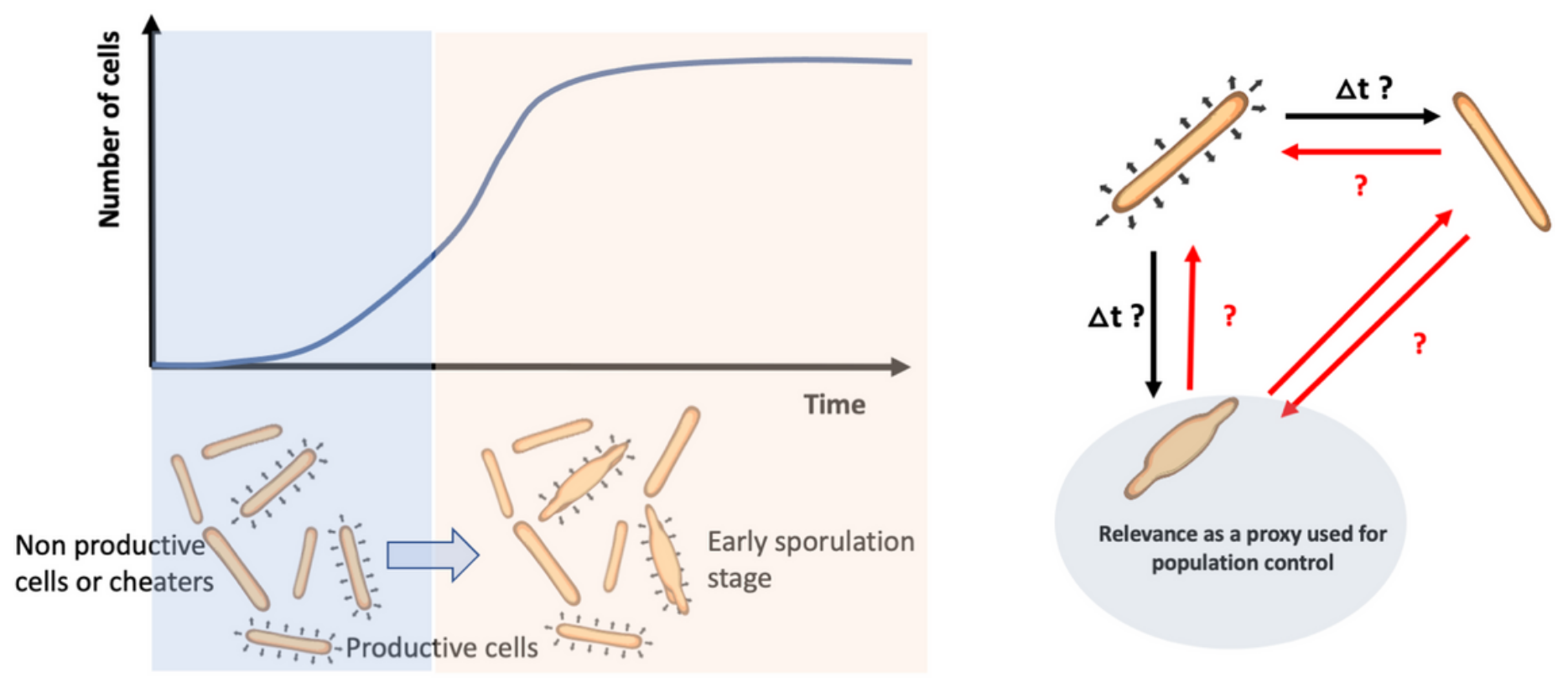

Relevance as a proxy used for population control

\section{Figure 8}

Model for T. xylanilyticus diversification at the population (A) and single-cell level (B).

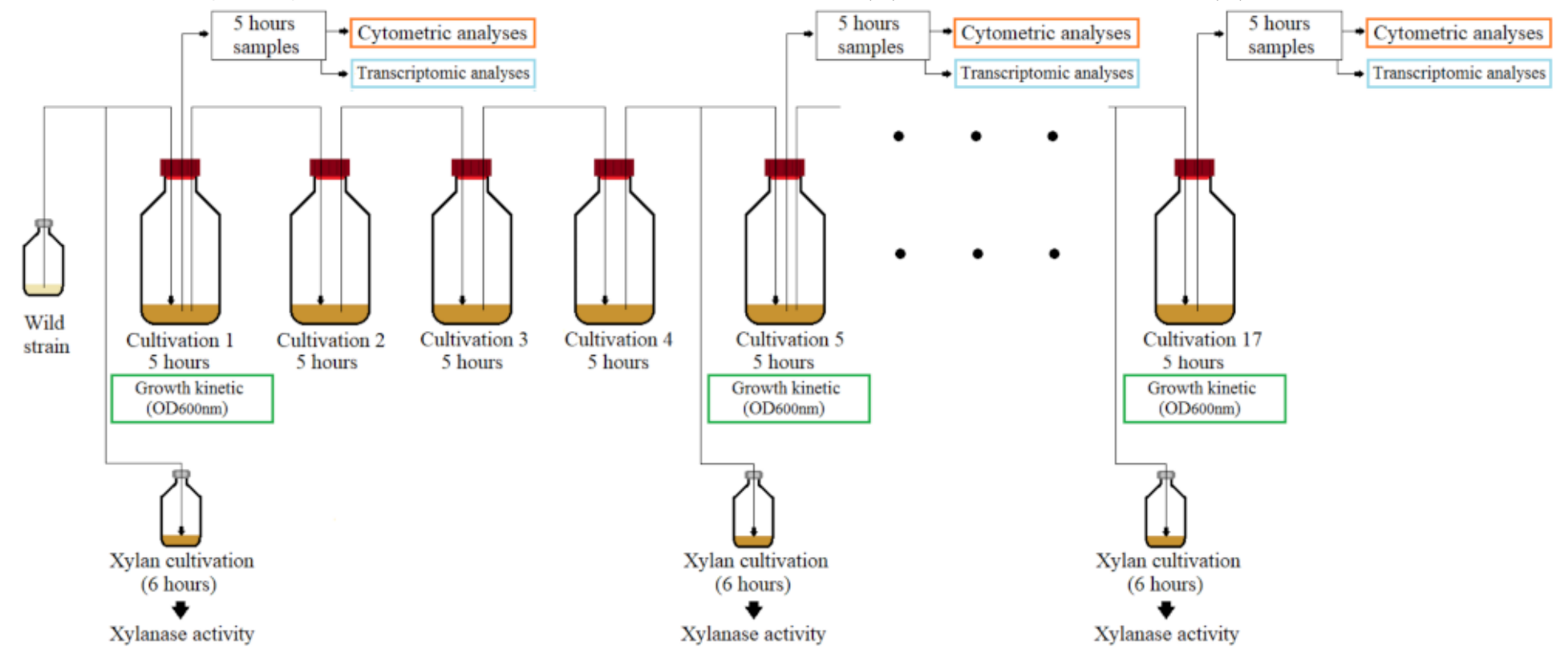

Figure 9

Schematic representation of the successive cultivations experiment of Thermobacillus xylanilyticus. 


\section{Supplementary Files}

This is a list of supplementary files associated with this preprint. Click to download.

- Additionalfiles.docx 